\title{
Factors contributing to municipal splits in Slovenia
}

\begin{abstract}
Slovenian communities were eager to re-establish autonomous local governments after the introduction of democracy. These newly established municipalities corresponded territorially to the previous regime's local communities; however, only 194 municipalities were formed from over 1,200 communities. Some municipalities comprised a cluster of communities, some of which later became proponents of splits, due to the sense that they were being neglected by the rest of the municipality and in the hope of receiving more funds as separate municipalities. Although stricter criteria for establishing municipalities were imposed and the scope of formal initiators was narrowed to limit the splits, the proponents found loopholes in the form of political patrons (deputies) and, as a last resort, sought justice from the constitutional court. The splits occurred in both underdeveloped and developed municipalities. The breakaway municipalities were not more developed than the mother municipality; about a third were less developed. There were no clear financial advantages in creating separate municipalities.
\end{abstract}

Keywords

Fragmentation - municipal splits - local self-government reform • local referendum $\bullet$ local finances

(C) University of Warsaw - Faculty of Geography and Regional Studies
Irena Bačlija Brajnik $\mathbb{C}^{1}$ Roman Lavtar $\mathbb{G}^{2}$

${ }^{1}$ Faculty for Social Sciences, University of Ljubljana, Ljubljana, Slovenia

e-mail: irena.baclija-brajnik@fdv.uni-l.j.si

¿Local Self-Government Service, Ministry for Public Administration, Ljubljana, Slovenia e-mail: roman.lavtar@gov.si

Received: 7 May 2020

Accepted: 1 July 2020
Introduction

$(R e)$ drawing the map of municipalities is (to some extent) a reflection of citizens' interests. Therefore, the map can change continuously (see Barometer of Local Institutional Reforms in Europe 2020). The creation of numerous municipalities is often interpreted as a reaction to previous compulsory, non-democratic merger reforms imposed by communist regimes (Illner 2010). Indeed, economic rationality and economies of scale were not the primary concern in Slovenia after its declaration of independence in 1991. Instead, based on the newly found "democratic" ethos, the citizen's will (as expressed in the local referendum) was the only criterion for establishing municipalities (Šmidovnik 1995). Due to the desire to "give the people voice", almost all other criteria were overshadowed.

Later, the Local Self-Government Act established in 1993 did set minimal standards for establishing municipalities, requiring that municipalities had at least 5,000 inhabitants and some infrastructure. This provision was not accepted well in most local communities, though, and a decision was made to allow exceptions (fewer than 5,000 inhabitants, but not fewer than $2.000)^{1}$ for territorial, historical or economic reasons. The pressure on legislators to loosen the criteria indicated that the municipal map was not final and that additional, small municipalities would be established. ${ }^{2}$ Indeed, the process of fragmentation continued; after the initial establishment of 147 municipalities in 1994, another 45 municipalities split in 1998, an additional one split

1 In 2010 , this provision was changed back to the minimum of 5,000 inhabitants.

2 Over half of the municipalities in Slovenia now have fewer than 5,000 inhabitants. in 2002, 17 municipalities split in 2006, and two split in 2010. Altogether, there are now 212 municipalities.

The aim of this paper is twofold. First, it aims to present an overview of municipal fragmentation in Slovenia. It will briefly present the history of Slovenia from the mid-1800s, providing more detailed descriptions of events that have occurred since the introduction of "full-fledged" local self-government systems. The territorial path dependency is important for understanding why the splits occurred. Entities representing the lowest level of "participation in social life" (as officially termed at the time) in the previous regime were the so-called "krajevne skupnosti" (hereafter "local communities", always in quotation marks to amplify the institutional rather than social meaning), which acted as sub-municipal units. These "local communities" were so embedded in the social and political fibre of the local population that almost all municipal splits were based on their previous territorial borders. Thus, parts of municipalities (that were established in 1994 as clusters of "local communities") were not satisfied with their position within the municipality and initiated a split.

The second aim of the paper is to discuss the reasons for dissatisfaction. A map of the new municipalities was drawn on the old map of over 1,200 "local communities" (clusters of "local communities" became one municipality; Vlaj 1998). This showed that demands for splits arose mostly from one or more "local communities" within newly established municipalities; there seems to be an argument for a cultural factor - a prevailing local identification. However, the question remains as to why some 
"local communities" pushed for splits from old municipalities and some did not. This paper will explain the possible factors behind the splits according to the categorisation offered by Swianiewicz (this volume): economic, cultural and political factors.

\section{Overview of Municipal Splits}

The origin of local governments in Slovenia can be dated to the mid-1800s, when the first municipal councils were elected after the adoption of the new constitution (in 1849) by the Habsburg monarchy. These entities were geographically based on cadastral municipalities, and over 1,100 municipalities were established and remained until WWI. Between WWI and WWII, the municipalities amalgamated, as new legislation set a minimum of 3,000 inhabitants per municipality. In 1955, the municipalities were replaced with 62 so-called socio-political communities (družbeno politične skupnosti, hereafter "socialistic municipalities").

By function, the socialistic municipalities were to replace the previous municipalities, but they acted more like administrative units of the state (Vlaj 1998). According to Vlaj (2001), about $80 \%$ of their operations included performing tasks in the name of the state, even though the Constitution stated that they were to carry out all relevant functions in the territory. The transformation of municipalities to socialistic municipalities (not just a territorial change, from a few hundred to 62 municipalities, but also a major role change) left a void in local political life that was later filled by the introduction of "local communities" (territorially smaller parts of socialistic municipalities, as these were too big, with over 30,000 inhabitants, to successfully address local interests). According to Vlaj (1998), "local communities" were organically formed and were only later officially recognised in 1963 (in legal acts) as some type of public entity. They acted as points of leverage for solving local problems and were successful in addressing local affairs such as issues with sewage systems, so socialistic municipalities were in favour of delegating local tasks to them. While Vlaj (1998) argued that local self-government developed in "local communities" to some extent, others (e.g., Šmidovnik 1993) saw these communities more as groups of citizens gathered on a voluntary basis.

Slovenia implemented a local self-government system in 1993 after declaring independence in 1991 and introducing a democratic regime. Knowing the process by which the municipalities were established is important for understanding further splits, because the way the new municipal map was drawn obviously caused some parts of the new municipalities later to seek "independence". New municipal maps were proposed by the government based on out-sourced expert studies. ${ }^{3}$ Two options were proposed: one with 163 municipalities (a minimum of 5,000 inhabitants) and one with 249 municipalities (a minimum of 2,000 inhabitants). ${ }^{4}$ These proposals were then given to socialistic municipalities, which held citizens' assemblies ${ }^{5}$ in over 1,200 "local communities" to collect local opinions and proposals on the given maps. Based on these local proposals, the government drafted a list of 340 referendum territories (Vrišer 1991) for parliamentary procedure. In most cases, citizens' opinions were included in the proposal; however, in cases where functionality was hampered (e.g., municipalities without a centre, municipalities that were too

\footnotetext{
3 The studies included more territorial institutions to serve as a draft proposal for the municipal map, including settlements, cadastral municipalities, municipalities from 1952-55 and municipalities before WWII. A final proposal based on "local communities" prevailed (Reporter of Assembly of Republic of Slovenia, 30 March 1992, pp. 23-24). 4 No maximum number of inhabitants was set.

5 The Constitution and the Local Self-Government Act defined the forms of direct citizen participation in decision-making concerning local public affairs; these included citizens' assemblies, local referendums and people's initiatives. At citizens' assemblies, the citizens discussed individual matters in the competence of the municipality and made proposals or passed decisions.
}

small, or proposals for municipalities as "islands" within another municipality) expert opinion prevailed (see Vlaj 1998). Most commonly, the citizens' opinions were connected to the following: establishing even smaller municipalities than those proposed by the government, establishing larger municipalities than proposed, splitting settlements (basic geographic units), splitting "local communities", etc. The borders of the newly proposed municipal territories were drawn on the map with the existing borders of "local communities"; this amplified the territorial connection to the old structures.

Local referendums were held in the proposed 340 areas in 1994, and the citizens were asked if they were in favour of establishing an individual municipality (each voter could only vote for or against establishment of the municipality as proposed by the final governmental map). These referendums were successful in 147 areas, causing 147 municipalities to be established after the first local elections in December 1994.

After the municipalities were established in 1994, there were two larger groups of splits. One occurred in 1998, when 45 new municipalities were established. In all 45 cases, new municipalities were formed on territories coinciding with the territories of the "local communities" that had expressed interest in a split. The other larger group of splits occurred in 2006, when 17 new municipalities were established. Again, this split was territorially coherent with old "local communities" (drawn on the borders of one or more "local communities"). In between these two larger groups of splits, one municipality was established in 2002. The last two were established later in 2011. More initiatives to split were made, but they were not successful for various reasons; a) not fulfilling legal requirements for establishment; b) lacking sufficient political support at the national level (initiators were not able to assure support from enough deputies to vote for the establishment of the municipality); c) negative results from a local referendum, thus a majority of citizens having voted against the split (e.g., in 2009 an initiative was made to establish six new municipalities by dividing a large urban municipality, Koper, but it was not supported by the citizens).

According to size, the splits produced small municipalities (see Table 1), most with fewer than 5,000 inhabitants and some with 5,000-10,000 inhabitants.

Geographically, splits were more common in the eastern part of the country, where the terrain is flat and unobstructed. Also, the splits were mostly not a result of suburban areas divorcing from urban centres, a process observed by Kaczmerk (2016) in Upper Silesia in Poland. There, suburban communes that were artificially united before 1989 into conglomerate towns split from urban centres. In Slovenia there are only two urban areas and they did not act as a centrifugal force for the splits. The map (see Map 1) shows there is no significant geographical cause for the splits.

\section{Legal Framework for the Splits ${ }^{6}$}

The establishment of municipalities in 1994 followed the Establishment of Municipalities and Municipal Boundaries Act. All subsequent establishments of municipalities followed the Procedure for Establishing Municipalities and Municipal Boundaries Act. In 1994, the only criterion for municipal establishment was a positive outcome in a local referendum. However, this was soon amended when the National Assembly adopted changes to the act and predefined a list of criteria for municipal establishment. This establishment of criteria

6 This section presents legislation that defined how the municipality was established either by split or merger. However, only splits (and no mergers) have occurred in Slovenia so far (although mergers are financially incentivised). Therefore, the presented legal framework regarding the establishment of a municipality should be understood within the concept of this paper: establishing municipalities via a split. 
MISCELLANEA GEOGRAPHICA - REGIONAL STUDIES ON DEVELOPMENT

Vol. $25 \cdot$ No. $1 \cdot 2021 \cdot$ pp. 54-61 • ISSN: 2084-6118 • DOI: 10.2478/mgrsd-2020-0026

Table 1. Sizes of municipalities after every split

\begin{tabular}{|c|c|c|c|c|c|c|c|c|c|c|}
\hline \multirow{2}{*}{ No. of inhabitants } & \multicolumn{9}{|c|}{ No. of municipalities (\%) } \\
\cline { 2 - 15 } & \multicolumn{2}{|c|}{1994} & \multicolumn{2}{|c|}{1998} & \multicolumn{2}{|c|}{2002} & \multicolumn{2}{|c|}{2006} & \multicolumn{2}{|c|}{2010} \\
\hline Fewer than 5,000 & 51 & 34.7 & 95 & 49.48 & 94 & 48.7 & 111 & 52.86 & 111 & 52.1 \\
\hline $5,001-10,000$ & 39 & 26.53 & 42 & 21.88 & 46 & 23.83 & 47 & 22.38 & 48 & 22.8 \\
\hline $10,001-50,000$ & 52 & 35.37 & 52 & 27.08 & 50 & 25.91 & 49 & 23.33 & 49 & 23.2 \\
\hline $50,001-100,000$ & 3 & 2.04 & 1 & 0.52 & 1 & 0.52 & 1 & 0.48 & 2 & 0.95 \\
\hline More than 100,000 & 2 & 1.36 & 2 & 1.04 & 2 & 1.04 & 2 & 0.95 & 2 & 0.95 \\
\hline Total & 147 & 100 & 192 & 100 & 193 & 100 & 210 & 100 & 212 & 100 \\
\hline
\end{tabular}

Source: Own elaboration

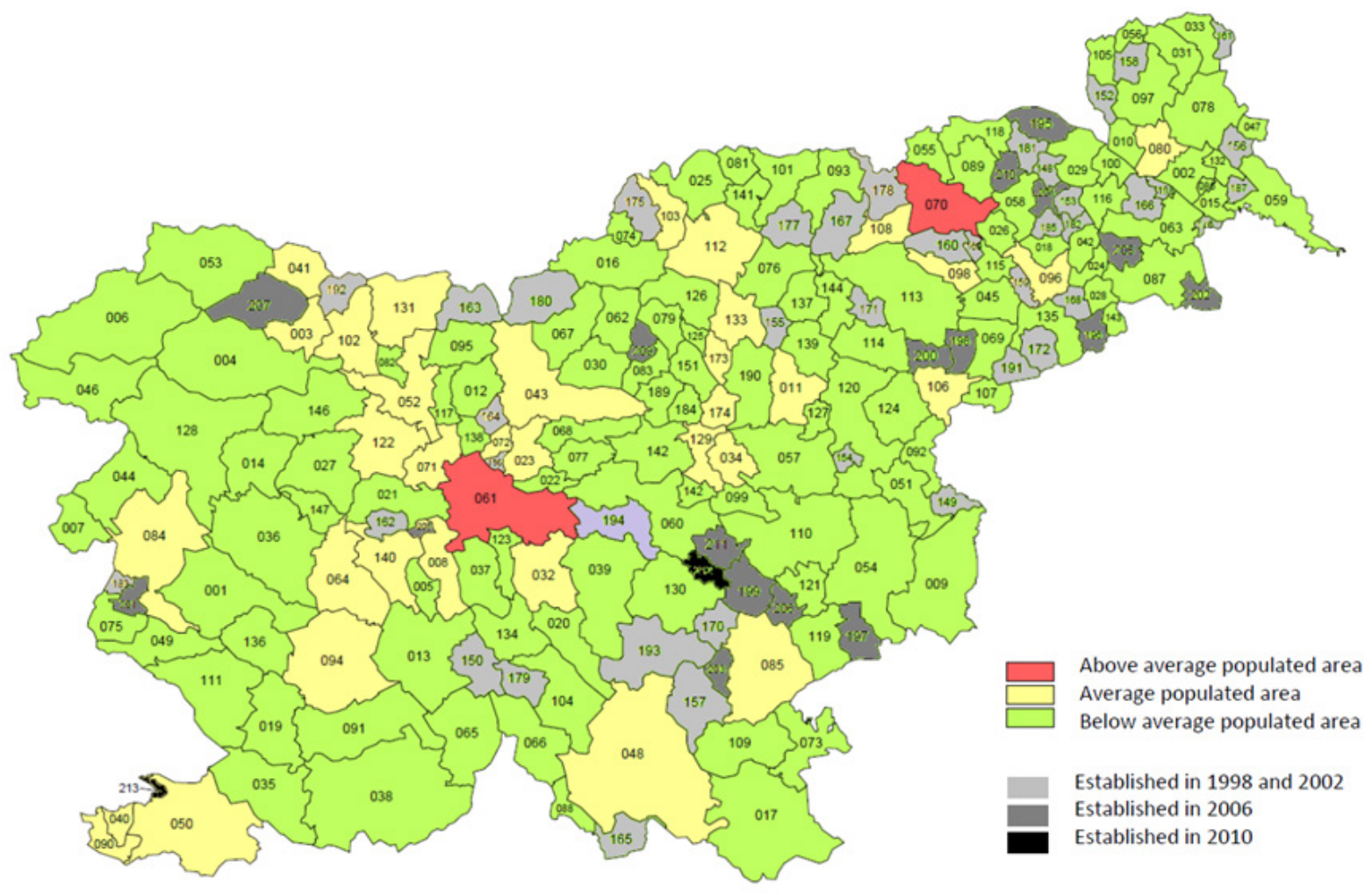

Map 1. Map of municipalities in Slovenia according to time of establishment and population density

Source: Adapted from Statistical Office of the Republic of Slovenia (2020), additionally marking municipalities that split post 1994

* Municipalities are numbered; list of municipalities with corresponding numbers available at the National Statistical Office (2020a)

considered the results of previous local referendums. The objective of these newly set criteria was, according to Šmidovnik (1995), to prevent the establishment of municipalities that were too small or too large (a maximum threshold was never set). The criteria were that the proposed municipality have a minimum of 5,000 inhabitants (although exceptions were allowed due to territorial, ethnic, historical or economic reasons) and a certain infrastructure. Later, these criteria were amended to prevent further fragmentation, since many new municipalities were established with a population of fewer than 5,000 .

In 2005, the content of the Procedure for Establishing Municipalities and Municipal Boundaries Act was incorporated into an umbrella law for local self-government that instituted the criteria for municipal establishment. New provisions allowed the establishment of municipalities with fewer than 5,000 inhabitants but not fewer than 2,000 when criteria for the abovementioned exceptions were met (i.e., territorial, ethnic, historical or economic reasons). These changes led to the establishment of 17 new municipalities only a year after the amended act was adopted. A second change in criteria came about in 2010, when the Local Self-Government Act was amended and no more exceptions below the 5,000-inhabitant threshold were allow.

Currently, the procedure for establishing new municipalities is given in the Local Self-Government Act. Under the law, new 
municipalities can be established after local inhabitants express their will regarding a split/merger in a local referendum. ${ }^{7}$ Citizen's will is of utmost importance and is protected by the Constitution, which specifically stipulates that municipalities can be established only after a local referendum. According to the Local SelfGovernment Act, new municipalities must be established with a name, territory, number of municipal councillors and other factors needed for municipal functioning (Article 12). As explained, the limit for establishing municipalities (Article 13a) is set to at least 5,000 inhabitants; however, an exception for fewer inhabitants is possible when a new municipality is established by way of a merger of two or more municipalities. Besides the minimal number of inhabitants, the municipality has to have the capacity to perform obligatory tasks. ${ }^{8}$

The Local Self-Government Act also states that municipal assets and debts should be divided by mutual agreement in the case of a split (Article 51b). This division should be enacted by the municipal councils within six months of consulting with each other. If this agreement is not met, the law (Article 51c) defines the outlines for division of assets so that immovable assets (e.g., public infrastructure) and movable assets intended for the use of immovable assets become the property of the municipality in whose territory they are located, while other property rights, funds and securities are allocated in proportion to the number of inhabitants. The potential debt on the immovable and movable assets (e.g., mortgage) is also divided.

Although the criterion for the number of inhabitants is important and is the most commonly debated one in Slovenia, other changes in legislation have also been made regarding municipality establishment. For example, a change was made as to who was eligible to initiate the establishment of a municipality. Before 2005, eligible initiators were as follows: those granted legal initiative according to the Constitution (deputies, the government, National Council and at least 5,000 voters), the National Assembly's working group in charge of local self-government, municipal councils or sub-municipal units. Initiators had to prepare a proposal that included arguments for establishing the new municipality, as well as a calculation that showed that both new entities (the newly proposed municipality and the remaining municipality) fulfilled the minimal criteria for establishing a municipality. The change of legislation in 2005 narrowed the scope of legitimate initiators and excluded sub-municipal units. This had a profound effect, since most sub-municipal units territorially corresponded to "local communities" from the former regime- the same entities that were major initiators of splits. The new legislation hampered the capacity of most common proponents for splits from initiating the process. This paper will later discuss how this affected the initiating process.

Before the changes to legislation in 2005, the procedure for establishing municipalities was stipulated in the Establishment of Municipalities and Municipal Boundaries Act (1996). Based on the act, the initiator had to submit supporting documents to the government (reasons for establishment either through merging or splitting the municipality, data that proved the proposed municipality fulfilled legal requirements for establishment, data

7 Although this provision prevents the establishment of a municipality that is not supported by the citizens, this "democratic" tool can be misused. In 2006, a proposal was made to establish the municipality Mokronog-Trebelno by splitting it from the much larger Trebnje municipality. The proposed municipality included two parts (former "local communities"), Mokronog and Trebelno. Mokronog was not able to initiate a split on its own, so proposed that both entities split from Trebnje. Since Mokronog was larger than Trebelno, they outvoted the people of Trebelno at a local referendum. The citizens of Trebelno disputed this process, but they were not successful and the municipality of Mokronog-Trebelno was established (Bačlija 2007).

8 Legal requirements for establishing a municipality are (aside from minimal number of inhabitants, whose threshold varied over the years) primary school, primary healthcare, water supply and sewage system, post office, library and office space for municipal administration. that proved the remaining municipality fulfilled legal requirements for establishment, data showing the reasons for exception if the proposed municipality would have fewer than 5,000 inhabitants, and the proposed name and centre of the municipality). If the proposal was in line with legislation, the government initiated a local referendum on the proposed territory. If the outcome of the referendum was positive, the government sent the draft law for municipal establishment to the National Assembly.

After the changes in 2005 , the procedure did not differ from that for proposing any other law. Eligible initiators (deputies, government, the National Council and at least 5,000 voters) can propose a draft law for municipal establishment accompanied by supporting documentation (reasons for the adoption of the law, regulatory impact assessments, etc.). Afterwards, the government is asked for its opinion on the establishment. If all legal requirements are met, a local referendum is initiated.

\section{Underlying Causes of Splits}

When categorising the factors behind the splits, a "cultural factor" (Swianiewicz, this volume) is evident in the municipal map being drawn on the map of old "local communities". Section 2 established that the parts of municipalities that initiated splits corresponded territorially to old "local communities" (one or more together) - entities that, according to Vlaj (1998), informally served as municipalities in the previous regime (although they were parts of larger areas that were formal municipalities). However, the statement that "a variant of a cultural push is rooted in the memory of having one's own, autonomous local government in the previous years" (Swianiewicz this volume) does not apply directly, as "local communities" were not autonomous local governments. As observed by Swianiewicz (this volume), this type of secession, a reaction to the forced amalgamation implemented under the communist regime, was the most typical form of split to occur in the early political transitions in Central and Eastern Europe. Indeed, it led to a rapid increase in the number of municipalities in several countries.

Cultural factors alone cannot fully explain why the splits occurred, since not all "local communities" initiated a split (there were about 1,200 "local communities" and there are currently 212 municipalities). Therefore, additional factors behind the splits must exist. According to the proposed categorisation-political and economic factors-they are presented in this paper in two sections; however, the factors probably overlapped in many cases.

\section{Political factors: bottom-up citizens' initiatives}

Political parties in Slovenia never had a unified vision of local self-government development. For example, regions have still not been implemented, although they are stipulated in the Constitution. The first version of the Local Self-Government Act (1993) did not even include provisions on the criterion of size for establishing municipalities, and the first wave of municipal establishments as the reformation of the system was based almost exclusively on citizens' initiatives and the establishments were confirmed by referendums. To understand what role politics played in the splits, the initiators must be examined, specifically in terms of whether they were politicians from the part of the municipality undertaking the initiative, from the existing municipality, from the central government, or from the national level.

According to the above-mentioned procedure, the official proponent behind municipality establishment in 1994 and the first wave of splits in 1998 was the government (at that time, the left-wing coalition)..$^{9}$ However, the real actors behind the

9 Formally, these were government proposals, but as explained previously, the government prepared an expert-based map that was then given to old municipalities, 
establishments and splits were local populations and politicians. Deputies in the National Assembly were pressured by their constituents to establish municipalities in specific territories. Therefore, the splits were not a partisan issue, as deputies across party lines supported new municipalities according to territory. All 45 municipalities that split in 1998 corresponded territorially to old "local communities"; thus, the splits were initiated by parts of municipalities that were not happy in the newly established municipality. In a way, they were stimulated by the provisions in the Establishment of Municipalities and Municipal Boundaries Act in 1994 that stipulated the maintained activity of "local communities" in the municipality until sub-municipal units were implemented. Activities in these (sub)local councils most likely led to calls for splits.

In 2006, when the second large group of splits occurred, new legislation was in place that excluded "local communities" from the list of eligible initiators. Therefore, to overcome legal provisions, "local communities" utilised different channels to propose splits (Bačlija 2007). ${ }^{10}$ The majority (13 out of 17) of these splits were officially proposed by deputies, and the other four were proposed by municipal councils (the councils of the mother municipality). Some of these splits were already proposed in 2001 by municipal councils but later opted for proposal by a deputy even though the municipal council was not opposed to the split (i.e., Šentrupert and Rečica ob Savinji). However, some municipalities did change their position on splits. For example, the Vrhnika municipality initiated the split of its smaller unit LogDragomer in 2001 and then openly opposed the split in 2005. Many other municipalities (Gornja Radgona, Krško, Vrhnika, Nova Gorica, Lenart and Ormož) also opposed the fragmentation of their territory. ${ }^{11}$

All 13 proposals from deputies were made by right-wing party members who formed a government coalition at the time (the right-wing government changed the legal framework and enabled the establishment of smaller municipalities of under 5,000 but not fewer than 2,000 inhabitants); they acted as formal initiators of the process in the National Assembly. ${ }^{12}$ As every proposition had to be accompanied by supporting documents arguing the establishment of the new municipality, the de facto initiator prepared these supporting documents. ${ }^{13}$ All 13 proposals were prepared by sub-local entities and were signed by the presidents of the then still-working "local communities".

Local political actors' rationale for proposing the splits must be determined, such as whether the local political leaders,

which held citizens' assemblies in over 1,200 "local communities" to collect local opinions and proposals on given maps. Based on local proposals, the government drafted a list of 340 referendum territories for parliamentary procedure.

10 Some "local communities" tried to split before 2006. When 34 proposals were sen to the National Assembly in 2001, among them were 13 of those that later succeeded in 2006 (Cirkulane, Gorje, Kostanjevica na Krki, Log-Dragomer, Makole, Mokronog, Poljčane, Rečica ob Savinji, Renče-Vogrsko, Središče ob Dravi, Straža, Sveti Jurij pri Slovenskih goricah, Sveti Tomaž and Šentrupert). As this was before restrictions were imposed regarding possible initiators, 17 municipalities were proposed by "local communities", 13 were proposed by municipal councils, four were proposed by deputies and two were proposed by initiative committees. At the time, only one proposal was successful (Šmartno pri Litiji).

11 Although noteworthy for analysing political factors for the splits, the positive opinions of remaining municipalities were not obligatory for establishing new municipalities.

12 The Polish example suggests that finding influential central level politicians to be a patron of the split was an effective strategy of initiators (Swianiewicz et al., 2018).

13 Before legislation changes in 2005, the Establishment of Municipalities and Municipal Boundaries Act (1996) listed what supporting documents had to be presented when a municipal establishment was proposed. These included the following: reasons for establishment (either by merging or splitting) of the municipality; data proving that the proposed municipality fulfilled the legal requirements for establishment; data proving that the remaining part of the municipality fulfilled legal requirements for establishment; if the proposed municipality would have fewer than 5,000 inhabitants, reasons why the municipality was an exception (geographical, historical, economical, ... ); proposed name and centre of the municipality. presidents and councillors from "local communities" had a personal investment in creating new municipalities and in running for office in the newly established municipalities. To establish rationale, the 2006 splits were analysed by cross-checking the names of the de facto proponents of the split with the names of candidates in the first elections in the newly established municipalities. These analyses (Bačlija 2007) concluded that 14 proponents later ran for office in the first elections. In all but four municipalities, at least one candidate for local councillor or mayor, nine for mayor and five for municipal councillor also appeared on the list of proponents. In the end, three mayoral candidates, all three presidents of previous "local communities" and only two councillors were elected. Of the 17 elected mayors, 11 were non-partisan and six were rightwing party candidates. Interestingly, all three presidents of "local communities" were also right-wing party candidates. Therefore, some type of ideological linkage existed, as many of the elected councillors ran as right-wing candidates and a right-wing-based coalition was formed in eight municipal councils. Local proponents were probably encouraged by the national right-wing party coalition, which was in favour of establishing new municipalities; however, other proponents were not excluded.

The prominent role of national politics was again expressed in the last two splits (Mirna and Ankaran) when, under a left-wing government, legislation changed again and did not allow the establishment of municipalities of under 5,000 inhabitants. Both proposed splits were based on the same arguments, and both proponents fulfilled the criteria for establishing the municipality. Although Mirna was established, the mayor of Koper, from which Ankaran wanted to split, publicly and strongly opposed the split, as it would also territorially split an important port and part of the tax revenue of the port would be reallocated to Ankaran. These pressures caused the National Assembly to delay establishing Ankaran. However, politics could not outweigh the rule of law. The Constitutional Court ruled that the National Assembly had violated the Constitution by deciding not to establish Ankaran, specifically violating articles related to the criteria for establishing municipalities; the criteria were met, but the National Assembly refused to adopt the law for establishment.

\section{Economic factors: the right to disburse the individual budget}

There are two major economic factors behind the splits. The first is related to the secession of the rich, and the second is the municipality's perception of being neglected by the rest of the municipality (see Swianiewicz this volume). Erlingsson (2005) and Brink (2004) argued that the richer part of the municipality may be inclined to split from the less affluent part, even when a strong fiscal equalisation mechanism exists. However, this was not a major factor behind the splits in Slovenia, as only one newly established municipality was financially better off after the split (see below).

Another important economic driver for municipal splits is the perception by parts of the municipality (i.e., the former "local communities") of being neglected by the larger, more urban part of the municipality with better infrastructure. As the amount of finances intended for the municipalities did not fluctuate with the rising number of municipalities, many proposed splits were a consequence of smaller and poorer parts of municipalities wanting to "get their piece of the pie". This was directly linked to the local government financing system. When specifying the material basis, the legislator was obliged to derive from Article 142 of the Constitution, while the scope of the material basis had to comply with the tasks the municipality would perform within its area of operations. An adequate relationship had to exist between the revenues of a particular municipality and the constitutional and legal tasks that the municipality was supposed to perform (Brezovnik \& Oplotnik 2014). 
Table 2. Political actors behind the splits in 2007

\begin{tabular}{|c|c|c|c|}
\hline \multirow{2}{*}{$\begin{array}{c}\text { Municipalities } \\
\text { established in } 2006\end{array}$} & \multirow[t]{2}{*}{ Official proposer of the split } & \multirow[t]{2}{*}{ De facto initiator } & $\begin{array}{l}\text { How many de facto initiators } \\
\text { ran for office }\end{array}$ \\
\hline & & & $\ldots$ and won office \\
\hline \multirow[t]{2}{*}{ Apače } & \multirow{2}{*}{ Deputy (right-wing party) } & \multirow{2}{*}{ "Local community" } & 1 \\
\hline & & & 1 \\
\hline \multirow{2}{*}{ Cirkulane } & \multirow{2}{*}{ Deputy (right-wing party) } & \multirow{2}{*}{ Local committee for split } & 1 - mayor, 2 - councillors \\
\hline & & & $1-$ councillor \\
\hline \multirow{2}{*}{ Gorje } & \multirow{2}{*}{ Bled Municipal council } & \multirow{2}{*}{ Local initiative } & 1 \\
\hline & & & 1 \\
\hline \multirow{2}{*}{ Kostanjevica na Krki } & \multirow{2}{*}{ Deputy (right-wing party) } & \multirow{2}{*}{ "Local community" } & 1 - councillor \\
\hline & & & $1-$ councillor \\
\hline \multirow[t]{2}{*}{ Log-Dragomer } & \multirow{2}{*}{ Deputy (right-wing party) } & \multirow{2}{*}{ "Local community" } & $1-$ councillor \\
\hline & & & I \\
\hline \multirow[t]{2}{*}{ Makole } & \multirow{2}{*}{$\begin{array}{l}\text { Slovenska Bistrica } \\
\text { Municipal council }\end{array}$} & \multirow{2}{*}{ "Local community" } & 1 - mayor \\
\hline & & & 1 \\
\hline \multirow[t]{2}{*}{ Mokronog-Trebelno } & \multirow{2}{*}{ Deputy (right-wing party) } & \multirow{2}{*}{$\begin{array}{l}\text { "Local community" Mokronog and } \\
\text { "Local community" Trebelno }\end{array}$} & 1 - mayor \\
\hline & & & 1 - mayor (nonpartisan) \\
\hline \multirow[t]{2}{*}{ Poljčane } & \multirow{2}{*}{ Deputy (right-wing party) } & \multirow{2}{*}{ "Local community" } & $1-$ mayor \\
\hline & & & $1-$ mayor (right-wing party) \\
\hline \multirow[t]{2}{*}{ Rečica ob Savinji } & \multirow{2}{*}{ Mozirje Municipal council } & Committee for establishment & $1-$ councillor \\
\hline & & & 1 \\
\hline Renče - Vogrsko & & & $1-$ mayor \\
\hline & Deputy (right-wing party) & "Local community" & 1 \\
\hline & & & 1 \\
\hline Sredisce ob Dravı & Deputy (rignt-wing party) & Local community & 1 \\
\hline Straža & & "Local community" & $1-$ mayor \\
\hline & Deputy (rignt-wing party) & Local community & 1 \\
\hline Sv. Jurij v Slovenskih & & "Local community" & 1 \\
\hline Goricah & Deputy (rignt-wing party) & Local community & 1 \\
\hline Sveta trojica v & & & $1-$ mayor \\
\hline Slovenskih Goricah & Deputy (right-wing party) & "Local community" & 1 \\
\hline Sveti Tomaž & Deputy (riaht-wing party) & "I ocal community" & $1-$ mayor \\
\hline & Deputy (nignt-wing party) & Local community & $1-$ mayor (right-wing party) \\
\hline Šentrupert & & & 1 \\
\hline & Deputy (rignt-Wing party) & Local community & 1 \\
\hline Šmarieške Toplice & Novo mesto Municipal & "Local community" & $1-$ mayor \\
\hline & council & Local cominturity & 1 \\
\hline
\end{tabular}

Source: Bačlija (2007)

The establishment of numerous small municipalities made it obvious that their financial autonomy would be hampered. The fiscal capacity of the new municipalities was mostly too weak to balance municipal obligatory tasks and the costs of these tasks. Therefore, the financing system was based on solidarity; the system of eligible costs per inhabitant was designed for larger municipalities (in terms of the number of inhabitants) to finance smaller ones. In the first four years after the system was established, the basis for financing the municipality was guaranteed expenditure, and municipalities were not fully autonomous in spending. As this was not in agreement with provisions of the European Charter of Local Government, the system was later amended, but the solidarity principle remained as the hub of the system (Lavtar 2018).

In 2006 and 2008, the financing system was amended; these amendments are still in effect. The main revenues of the municipality are personal income tax and property tax, which both represent over $60 \%$ of all local revenue. Property tax and most 
MISCELLANEA GEOGRAPHICA - REGIONAL STUDIES ON DEVELOPMENT

Vol. $25 \cdot$ No. $1 \cdot 2021 \cdot$ pp. 54-61 • ISSN: 2084-6118 • DOI: 10.2478/mgrsd-2020-0026

Table 3. Economic situation of municipalities before the split and economic situation of split municipality compared

\begin{tabular}{|c|c|c|}
\hline Economic situation of the "before the split" municipality & Economic situation of split municipality & Number of cases \\
\hline Above average & Above average & 23 \\
\hline Above average & Average & 13 \\
\hline Above average & Below average & 1 \\
\hline Average & Above average & 1 \\
\hline Average & Average & 14 \\
\hline Average & Below average & 4 \\
\hline Below average & Average & 1 \\
\hline Below average & Below average & 7 \\
\hline
\end{tabular}

Source: Own elaboration

other tax and non-tax revenues are set according to the territorial provision (thus, subjects and objects within the municipal territory are taxed), but personal income tax is allocated by the solidarity principle. Municipalities get $54 \%$ of the personal income tax, but the share of the income tax for individual municipalities is calculated according to relevant expenditure - that is, support for the performance of local government duties that are determined by the Constitution and law. The amount of local relevant expenditure per capita is determined by a formula that considers local population figures, the size of the territory and the length of local roads.

The financial system provided for smaller municipalities gaining relatively more revenue than larger municipalities. In 2019, almost two thirds (149) of the municipalities received more than average relevant expenditure per inhabitant, while 63 received less than average. Although common in countries with smaller municipalities, the financial equalisation ${ }^{14}$ system stimulated municipal splits, because new, smaller municipalities were reallocated sources from bigger centres.

Since no data exist on how much of the municipal budgets was allocated to "local communities" that later split, assessing whether the splits occurred because these parts were neglected or because they were economically opportunistic is difficult. This paper will assess how newly established municipalities financially performed vis-à-vis remaining municipalities by presenting how well they performed regarding the coefficient of municipal development. This coefficient is a national tool to establish which municipalities are underdeveloped, and it is used to calculate which municipalities are eligible for state (co) financing of municipal investments. The coefficient is based on the following data: gross added value per employed person, income tax per municipal inhabitant, number of workplaces per number of working population in the municipality, index of aging population, registered unemployment rate, working population in the municipality, number of inhabitants with access to the public sewage system, cultural objects and infrastructure,

14 The difference between income tax revenues and total municipal revenues from pertaining income tax as well as solidarity equalisation payments is what funds are used to provide an additional solidarity offset of municipalities from income tax. Additional solidarity equalisation for an individual municipality belongs to municipalities with a smaller eligible volume of funds than eligible expenditure, i.e., to the maximum amount of eligible expenditure. Additional solidarity equalisation is determined for each municipality from the percentage calculated by considering the difference between eligible expenditure of a municipality and its revenues derived from the pertaining income tax and solidarity aid, i.e. in the sum total of all differences of municipalities that are entitled to a further solidarity offset (Brezovnik \& Oplotnik 2014). share of territory under Natura 2000 and population density in the municipality. ${ }^{15}$ The coefficient is calculated annually, but the government started calculating it in 2008 , so data are not available for the time most of the splits occurred. However, some conclusions can be made based on existing data.

First, the municipal development coefficient from 2019 was divided into three categories: a) above average (coefficient over 100 ), b) average (coefficient from 85 to 99) and c) underdeveloped (coefficient under 85). Then, coefficient levels were compared between municipalities that remained and those that split. The splits occurred in municipalities that were developed above average and underdeveloped alike; therefore, development of the municipality does not seem to have played a significant role.

Two thirds of the municipalities (44 municipalities) that split after 1998 had the same coefficient value as the municipalities from which they split. Whether these municipalities had a lower index value that improved over time is unknown; however, due to included indicators, a high probability exists that the values did not change dramatically over time. Only two municipalities were financially better off (Oplotnica and Cankova-Tišina), while the remaining 18 were worse off. The parts that split were mostly not performing better developmentally. Therefore, scenarios of richer parts splitting from the less affluent are not realistic. The splits were more likely a consequence of being neglected by the mother municipality and of utilising the advantages of the equalisation mechanism. For example, the pre-referendum propaganda material in the Renče-Vogrsko municipality stated, "When we realise that we can't have less than we have now, we will make big progress!" (Bačlija 2007).

\section{Conclusion}

The nostalgia for "local communities" is evident among the citizens of Slovenia; the municipal map was drawn on the map of "local communities", and all splits were initiated by "local communities" (one or more) as well. "Local communities" were clearly embedded in the social and political fibre of the local population. However, out of more than 1,200 "local communities", only 212 municipalities were established. Therefore, many "local communities" decided to form clusters and stay together within one municipality. The question is what drove some of these "local communities" to go their separate ways. First, the splits might have been due to a so-called cultural push-a feeling of being special or different from the rest of the municipality. Although not

15 Article 3, Regulation on the methodology for determining the level of development of municipalities (Official Gazette of RS, no. 78/19) 
researched, splits might be linked to strong local political life in the previous regime. However, it is more likely that the main push came from a combination of economic and political factors. Due to the equalisation mechanism, smaller and poorer municipalities received reallocated funds from the larger and richer centres. This most probably prompted some "local communities" to rethink their position within their existing municipality. Here, political factors played a role, as active local political actors had to mobilise the citizens to demand a split. However, these actors mostly did not take control after the establishment, as only a few won office in the first elections.

No evidence exists that the new municipalities are now more developed. More often (in one third of cases), they are now less developed than their mother municipality. Therefore, if the projection was that they would be financially better off, they miscalculated. However, if the reasoning behind the split was to take control of their local environment, then the split was fruitful. The new municipalities are small, and in theory, citizens' interests are better represented.

Akcnoledgements

The authors would like to thank Paweł Swianiewicz and Adam Gendźwiłł for comments on an early draft, and anonymous reviewers for useful comments and suggestions.

ORCID

Irena Bačlija Brajnik (1D) https://orcid.org/0000-0002-9328-0982

Roman Lavtar (1D https://orcid.org/0000-0002-5110-2184

\section{References}

Bačlija, I 2007, 'Analiza nastajanja novih občin in prvih lokalnih volitev $v$ teh občinah' ['Analyses of establishment of new municipalities and their first elections'], Lex localis, vol. 5, no. 1, pp. 47-64.

Barometer of Local Institutional Reforms in Europe 2020. Available from: <https://barometre-reformes.eu/en/>. [2 February 2020].

Brezovnik, B \& Oplotnik, ŽJ 2014, Fiscal decentralisation in Slovenia, Lex Localis, Maribor.

Brink, A 2004, 'The break-up of municipalities: voting behavior in local referenda', Economics of Governance, vol. 5, no. 2, pp. 119-135.

Erlingsson, GO 2005, 'Modelling secessions from municipalities', Scandinavian Political Studies, vol. 28, no. 2, pp. 141-159.

Illner, M 2010, 'Top-down or bottom up? Coping with territorial fragmentation in the Czech Republic' in Territorial choice: The politics of boundaries and borders, eds $\mathrm{H}$ Baldersheim \& L Rose, Palgrave-Macmillan, London, pp. 214-233.

Kaczmarek, T 2016, 'Administrative division of Poland - 25 years of experience during the systemic transformation', EchoGéo, vol. 35, no. 1. Available from : <http://journals.openedition. org/echogeo/14514>. [28 June 2020].

Lavtar, R 2018, Evropska listina lokalne samoupravo in normativna preobrazba slovenske lokalne samouprave [European charter of local self-government and normative transformation of local self-government in Slovenia] in 20 let Evropske listine lokalne samouprave $v$ Sloveniji $[20$ years of ratifiction of European charter of local self-government in Slovenia] ed. I Rakar, Inštitut za lokalno samoupravo, Maribor, pp. 45-55.

Statistical Office of the Republic of Slovenia 2020, Level of urbanisation - Slovenia - municipalities. Available from: <https://www.stat.si/dokument/9485/Kartografski\%20 prikaz $\% 20$ občin $\% 20$ po\%20stopnji\%20urbanizacije $\% 20$ 2017.pdf>. [23 June 2020].

Statistical Office of the Republic of Slovenia 2020a, List of municipalities. Available from: <https://www.stat.si/statweb/ Methods/Classifications>. [23 June 2020].

Swianiewicz, P, Gendźwiłł, A \& Łukomska, J 2018, 'Inicjatorzy i opuszczeni: demokracja lokalna po gminnych rozwodach' (The initiators and the abandoned: local democracy after municipal divorces) Prace Geograficzne, vol. 154, pp. 7-33.

Swianiewicz, P 2021 'From post-communist democratic laissezfaire to prevention of territorial fragmentation: tightening the rules of municipal splits in Central and Eastern Europe after 1990', Miscellanea Geographica - Regional Studies on Development, vol. 25, no. 1, pp. 5-17.
Šmidovnik, J 1993, 'Strumno v centralizacijo: lokalna samouprava' ['Brave into centralisation: local self-government'], Delo, vol. 35 , no.77, pp. 2-8.

Šmidovnik, J 1995, Lokalna samouprava [Local self-government], Cankarjeva založba, Ljubljana.

Vlaj, S 1998, Lokalna samouprava [Local self-government], Fakulteta za družbene vede, Ljubljana.

Vlaj, S 2001, Lokalna samouprava: teorija in praksa [Local selfgovernment: theory and practice], Fakulteta za upravo, Ljubljana.

Vrišer, I 1991, Delovno gradivo o oblikovanju novih občin $v$ Republiki Sloveniji [Supporting documentation for establishing new municipalities in Slovenia], Vlada Republike Slovenije, Ljubljana. 